\section{Public-Private Partnerships as Alternative Public Procurement Instruments}

\section{Emmanuel Botlhale}

Department of Political and Administrative Studies, University of Botswana, Gaborone, Botswana

\section{Synonyms}

Alliance; Collaboration; Consociation; Cooperation; Sharing; Togetherness

\section{Definition}

There are various definitions of PPP; hence, a working definition is needed. PPP is "any arrangement between the government and the private sector in which partially or traditionally public activities are performed by the private sector" (Savas 2000: 4). PPPs have different synonyms such as P3s, Private Sector Participation (PSP) and Private Participation in Infrastructure (PPI). However, in common parlance and as it is in this chapter, the acronym PPP is used. PPP arrangements take many different forms, for example, DBFOM (Design, Build, Finance, Operate, and Maintain), DBFM (Design, Build, Finance, and Maintain), DCMF (Design, Construction, Maintain, and Finance), and DBFO (Design, Build
Finance, and Operate). Others are PFI (Private Finance Initiative, mainly used in the UK), concession, leasing of public works, joint ventures, and public service contracts. PPPs are mainly used to procure economic infrastructure such as railways, roads, airports, and ports and key services such as health, education, water, and electricity. This development equally happens in both the global north and south as there is a move to leverage on private capital.

\section{Introduction}

PPPs have an ages-old history, for example, they were used during the Roman Empire (27 BC-AD 4760. Even though PPP-style models of public investments have a long history, the acronym PPP gained currency in both academic and nonacademic circles in the 1970s, and, consequently, many books were being written on PPPs in the 1980s. However, the use of PPPs as an alternative to public-only investment saw phenomenal growth in the early 1990s with the advent of public sector reforms such as New Public Management. Following the launch of the Private Finance Initiative by the John Major-led government which involved the financing and construction of capital investment projects by a private company and the leasing back of the projects to the public sector over a predetermined period (usually, 25-30 years), the use of PPPs has gained worldwide use. Today, PPPs are increasingly becoming popular tools to deliver infrastructure 
and public services around the world. Throughout the industrialized and developing world, there has been a renewed move to liberalization and privatization of infrastructure activities from the 1980s and increasing dramatically into the 1990s (PPIAF 2009: 35). The global financial crisis of 2007-2009 provided an impetus for the renewed interest in PPPs in both developed and developing countries, particularly, the latter. It is notable that developing countries, particularly in sub-Saharan Africa (SSA), disproportionately suffered the effects of the global financial crisis largely due to their monocultural economies (i.e., economies that are disproportionately reliant on one primary export commodity e.g., Botswana is heavily dependent on diamonds). When the crisis hit, demand for primary export commodities such as base metals (e.g., diamonds) fell, leading to constrained fiscal envelopes. This fiscal reality forced primary products-reliant economies to look elsewhere for extra-public balance sheet financing of developmental and social infrastructure. Besides the foregoing, there is a general dissatisfaction with traditional public-only investment in the sense that there are deficits of Value for Money (VfM) (as measured in efficiency, effectiveness, and economy). Thus, it is contended that publiconly investment, owing to, among others, bureaucratization (bureaucratic rigidity, hence, little flexibility in decision-making) and poor public project implementation, results in little VfM.

Given the incontestable fact that PPPs have been adopted as an alternative to public-only investment, what are the drivers for the increased uptake of PPPs? There are many works be they textbooks, research reports, journal articles, conference papers and Internet articles that discuss these drivers. Some examples are Chan et al. (2009) and World Bank (2016). According to Chan et al. (2009), drivers for PPPs can be grouped under five categories: (i) equitable risk-sharing (i.e., achieving substantial risk transfer), (ii) cost savings and Value for Money (i.e., cost savings, VfM, and cost certainty), (iii) enhanced asset quality and service levels (i.e., time savings, time certainty, innovations in public services, and better maintenance of assets), (iv) reduced public financing (i.e., reduced public funding), and (v) catalyst for the economy (i.e., encouraging cooperation and enhancing social development and business opportunities. In a similar vein, World Bank (2016), among others, lists the following drivers: (i) exploring PPPs as a way of introducing private sector technology and innovation in providing better public services through improved operational efficiency; and (ii) incentivizing the private sector to deliver projects on time and within budget.

The foregoing does not suggest that PPPs. are risk-free; they are heavily freighted with many risks (Zhang 2005). In this regard, Charles (2006: 693) counsels that "for PPP to be successfully initiated and implemented, the presence of a conducive and enabling legal and regulatory framework is a critical prerequisite." In a related vein, PPIAF (2009: 83-84) argues that the enabling environment for the successful implementation of PPPs is composed of four components. These enablers are (i) public sector commitment, (ii) effective risk management, (iii) legal and regulatory framework, and (iv) capable public and private sectors. Therefore, it can be argued a priori that in the absence of an enabling environment as argued by, for example, PPIAF (2009), PPPs cannot measure up to the task, that is, deliver as per expectation. In this regard, to ensure successful PPP enterprises, there is a need to grow an enabling environment à la PPIAF (2009) and avoid PPP potential risks as enumerated by, among others, Ika (2012), World Bank (2016), and Zhang (2005). Despite potential risks as manifest in Ika (2012), World Bank (2016) and Zhang (2005), there is a big push for PPPs in public procurement instead of traditional procurement (see Burger and Hawkesworth 2011).

\section{Comparing Traditional Public Procurement and PPP}

When it comes to public procurement, the choice is often, at a broad level, between PPP and traditional public procurement (i.e., procurement that is solely publicly financed, mostly, using taxpayers money). Whether the government goes the route of PPP or traditional public procurement, there are decisional guides. Although there are many decisional guides to public procurement, 
the most overriding one is Value for Money (Burger and Hawkesworth 2011). Therefore, any project, whether it is a PPP or a traditionally procured project, should be undertaken only if it creates Value for Money (Burger and Hawkesworth 2011: 1). What is Value for Money (VfM)? Good Value for Money is the optimal use of resources to achieve the intended outcomes (UK National Audit Office 2020). VfM consists of three constituent components: (i) efficiency, (ii) effectiveness, and (iii) economy. They are defined as:

Efficiency: the relationship between the output from goods or services and the resources to produce them - spending well

Effectiveness: the relationship between the intended and actual results of public spending (outcomes) - spending wisely

Economy: minimizing the cost of resources used or required (inputs) - spending less (UK National Audit Office 2020)

Besides the 3 Es, a fourth E, equity, is often added. Equity is the extent to which services are available to and reach all people that they are intended to - spending fairly (UK National Audit Office 2020). Given resource scarcity, particularly given post-2007 fiscal strictures that are largely attributable to the 2007-2009 global financial crisis, the worst crisis after the 1929 Great Depression, VfM issues are imperatively critical in public procurement. On a balance of probabilities and given the right enabling environment (see Charles 2006; PPIAF 2009), PPP procurement may confer more VfM as compared with traditional public procurement. Broadly speaking, a PPP may provide Value for Money compared to traditional procurement models if the advantages of risk transfer combined with private sector incentives, experience, and innovation - in improved service delivery or efficiencies over the project life-time - outweigh the increased costs of contracting and financing (World Bank 2013: 8-9). Therefore, a VfM analysis is critical for it helps governments to choose how to implement projects; PPP or traditional forms of public procurement? However, it is notable that the VFM analysis is only a part of the PPP project appraisal process that includes, among others, commercial, technical, and economic viability and affordability or fiscal responsibility (World Bank 2013). VfM analysis is not a perfect science for it is still evolving, but it is widely used in some regions; an example is the Organization for Economic Co-operation and Development region. Anecdotal evidence suggests that, overall, and given an enabling environment, VfM analysis demonstrates that PPPs are superior to traditional public procurement. Due to this superiority, and all things being equal, PPP procurement is favored over traditional public procurement. Hence, "governments increasingly use public-private partnerships (PPPs) to pursue value for money" (Burger and Hawkesworth 2011: 1).

It is notable that to maximize Returns on Investment, it is not enough to only consider VfM in public procurement. Hence, some works, for example, Dimitri (2013), talk about Best Value for Money (BVM). BVM is a multi-criteria approach that considers factors such as price/ cost, quality, and sustainability to meet customers' requirements when deciding on procurement techniques: PPP or traditional public procurement? Therefore, BVM does not mean the lowest monetary cost but the best Return on Investment. BVM leads to Best Value Procurement (BVP), the antithesis of lowest-bid procurement. Thus, using $\mathrm{VfM}$ at a minimum, or BVM at a maximum, the weight of the evidence would recommend that public projects be delivered via the PPP vehicle. Given chronic resource scarcity in the developing world, particularly in sub-Saharan Africa (SSA), coupled with post-2007 fiscal strictures, the case for public procurement via PPPs in SSA is readily saleable as next demonstrated.

\section{The Case for PPP Procurement in the Developing World}

The developing world is too broad a region to cover under one chapter; therefore, the focus will be on Africa, particularly sub-Saharan Africa (SSA). The case for the adoption of PPPs in SSA 
is founded on many factors, but for brevity, this chapter will focus on three: (i) public project management maturity, (ii) post-2007 fiscal strictures, and (iii) COVID-19 pandemic.

It is trite that successful traditional public procurement is contingent upon many factors, the most important being public project management maturity. Public project management maturity refers to methodologies and processes that are used to implement public projects to ensure repeated successes as measured by VfM and BVM. These methodologies and processes are encapsulated in tools such as Governmental Project Implementation System (GPIS) and Governmental Project Management (GPM). While there are different experiences with public project management maturity owing to the diversity of the SSA subregion, the general picture is that of poor public project management maturity. As a result, a majority of public projects are not delivered as per the Project Management Triangle (called also the Triple Constraint, Iron Triangle and Project Triangle) of cost/budget, scope, or quality and time. Therefore, in a majority of cases in the SSA subregion, public projects, be they roads, dams, etc., are not delivered per cost/ budget, scope/quality, or in time.

This foregoing issue was intensely highlighted through a concept note of the Pan-African Project Management Conference (PMC) that was organized in Yaoundé, Cameroun, in November 2016. The overarching objective of the first edition of the Pan-African PMC was to underscore the centrality of project management in transforming African economies. The concept note argued that a technological gap in project management in Africa existed. It further argued that the project management gap was apparent in four areas: (i) the participation of African countries in International Organization for Standardization (ISO) committees; (ii) the number of Project Management Institute (PMI) chapters in Africa; (iii) the number of International Project Management Association (IPMA) member associations in Africa; and (iv) number of universities and higher institutes whose project management training programs were accredited. In a related note, Ika (2012) is instructive. Focusing on International
Development Projects, Ika argues that project management problems are due to the one-sizefits-all technical trap, the accountability for results trap, the lack of project management-capacity trap, and the cultural trap. Notably, project management capacity trap is one of the key causative factors of project failure. Hence, given these project management failures in SSA countries, PPPs are another solution in addition to reforming GPIS and GPM.

The global financial crisis (GFC) refers to the period of extreme financial stress in both global financial markets and banking systems between mid-2007 and early 2009. Some economists contend that the GFC was the most serious financial crisis since the Great Depression of the 1930s. As for origins, a downturn in the US housing market was a trigger for a financial crisis that spread from the USA to the rest of the world due to interconnectedness of financial systems as a result of economic globalization. Due to the nature of African economies, the majority of which are monocultural (i.e., relying on one major export - e.g., Botswana is overwhelmingly reliant on diamonds), they disproportionately suffered the effects of the GFC. The most significant effects were, still are, a decline in export prices and volumes. As a result, they are faced with reduced export earnings, hence, a reduced fiscal envelope. Reduced fiscal envelopes have ineluctably led to prolonged budget deficits. As an example, before 2008, Botswana enjoyed uninterrupted budget surpluses for over 20 years (see various budget reports). Post-2008, budget deficits are chronic. For example, as per the 2020/ 2021 Budget Strategy Paper, budget deficits will be Botswana Pula (1 Botswana Pula $(B W P)=0.084$ USD.) (BWP) -1, 9819 million; BWP -6, 345 million, BWP -7, 7875 million; BWP -6, 9415 million; and BWP -4, 4066 million in financial years 2017/ 2018, 2018/2019,2019/2020,2020/2021, and $2021 / 2022$, respectively. The situation in Botswana is replicated in almost all SSA countries. For example, as per the 2020/2021 South African budget speech, revenue is projected to be 1.58 trillion rands ( 1 South African Rand $=0.057$ USD), or $29.2 \%$ of the gross domestic product (GDP), and expenditure is projected at R 1.95 trillion or $36 \%$ of GDP. This, therefore, translates into a massive 
budget deficit of R370.5 billion or $6.8 \%$ of GDP in 2020/2021.

The question is how do SSA economies plug budget deficits? Although there are many options, the most potent one is the usage of private capital. That is, the governments must tap into private capital to finance economic growth and development and also finance infrastructure. This will entail the financing of growth and infrastructure through PPPs. For instance, when delivering the 2020 Nation of the State Address on 13 February 2020, South African President, Cyril Ramaphosa, proposed that pension funds, including those in the private sector, should be used to finance parastatals such as Eskom (a state power utility company). In a related vein, the government of Botswana has decided that most capital projects during the 11th National Development Plan period, 2017/18-2022//23, will be delivered as PPPs. So, PPPs will allow SSA economies to finance projects off the public balance sheet.

Latterly, the world is faced with the coronavirus disease (COVID-19), an infectious disease caused by a newly discovered coronavirus. COVID-19 is an evolving situation, but there are signs that it will wreak havoc on the global economy. In this regard, the International Monetary Fund (IMF) forecasts a global recession in 2020, and that the effects of COVID-19 will be as deleterious as those of the last global economic crisis. As of writing this chapter (27 March 2020), nearly 80 countries have asked the IMF for emergency finance. Like it happened during the last global economic crisis, countries are cobbling up economic stimulus packages. For example, in early March 2020, the US Congress approved one trillion Dollars as a coronavirus relief package. The same is being witnessed in the developing world as next illustrated. On 24 March 2020, African Ministers of Finance announced the need for African counties to adopt an immediate emergency economic stimulus to the tune of $\$ 100$ billion because of COVID-19-related economic disruptions. This call was contained in a press release issued after a virtual conference organized by the Economic Commission for Africa from its headquarters in Addis Ababa. The call also underscored the need to support the private sector and protect at-risk over 30 million jobs, particularly in the tourism and airline sectors across the continent, the two being major drivers of the economy beyond primary products. The foregoing augments individual country initiatives as next exemplified. On 2 March 2020, South African President, Cyril Ramaphosa, announced the establishment of a Solidarity Fund into which South African businesses, organizations, and individuals and members of the international community can contribute to fighting the spread of COVID-19. This is in addition to the government-financed stimulus package. In Botswana, in mid-March 2020, President Mokgweetsi Masisi announced that BWP 22 million had been set aside to fight COVID-19 and also stimulate the economy. It is within the realm of believability that other SSA countries, besides Botswana and South Africa, are cobbling up various economic stimulus packages to fight COVID-19 and also stimulate their economies.

Economic stimulus packages (ESPs) are usually huge projects (involving billions of US Dollars); therefore, the government cannot deliver ESP programs alone, largely, due to public project management maturity issues. The foregoing point was demonstrated during the ESP program that Botswana embarked upon in 2015-2018. The goals of ESP were to stimulate the economy; diversify the economy through Economic Diversification Drive (EDD) and Special Economic Zones (SEZs), and accelerate job creation. The government roped in the private sector to implement ESP projects. Hence, SSA countries must invite the private sector to help them implement COVID-related ESP projects via the PPPs vehicle.

\section{Way Forward in PPP Procurement}

It is important to reiterate that PPPs are not silver bullets. Therefore, they are fraught with considerable risks that may make them less desirable than traditional public procurement projects. In this regard, first things must happen first to ensure the successful implementation of PPP procurement. For the sake of brevity, a few "firsts" (or fundamentals) are discussed. 
Enabling environment: in terms of implementing any project, nothing is as important as an enabling environment. An enabling environment consists of two key components: (i) robust policy framework and (ii) governance institutions. Regarding a robust policy framework, this relates both to the regulatory and institutional architecture that spells out the rules of the game, for example, through PPP legislation (statutory acts) and regulations (these give effect to the act for the former is crafted in board strokes). In this regard, some jurisdictions have specific PPP laws, accompanied by attendant regulations. Some examples are Afghanistan (Public-Private Partnership Law 2016), Albania (Law on Public Procurement 2006), Angola (Lei Sobre as Parcerias Público Privadas [Law on public-private partnerships] 2011), and Benin (Benin Public Private Partnership Law [in French]). Likewise, PPP legislation must be guided by international guidelines such as UNCITRAL Guidance on Public-Private Partnership/Concession Laws (2000), EBRD Core Principles for a Modern Concession Law, and OECD Principles for Public Governance of Public-Private Partnerships. The United Nations Commission on International Trade Law (UNCITRAL) published a Legislative Guide on Privately Funded Infrastructure Projects in 2000. The purpose of the Guide is to assist member countries to establish a legal framework that guides private investment in public infrastructure. Concerning the EBRD Core Principles for a Modern Concession Law, the European Bank for Reconstruction and Development (EBRD) proposes a set of core principles as guidance for concession law. Lastly, the OECD Principles for Public Governance of Public-Private Partnerships provide concrete guidance to policymakers on how to make sure that Public-Private Partnerships (PPP) represent Value for Money for the public sector. Hence, PPP legislation must draw on the foregoing guidelines.

Regarding governance institutions, governments must establish departments (or units) that are solely responsible for PPP matters. In Botswana, for instance, a PPPs unit was established in 2016 in the Ministry of Finance and Economic Development to coordinate and oversee the implementation of the PPP Policy. Therefore, such PPP units must be established, given very clear mandates, and they must be properly resourced. Thus, they must be supported by adequate budgets and officered by staff trained in PPP management, not generalists.

In a related vein, PPIAF (2009: 83-84) counsels that the enabling environment for the successful implementation of PPPs is composed of four enabler components. These enablers are (i) public sector commitment, (ii) effective risk management, (iii) legal and regulatory framework, and (iv) capable public and private sectors. Therefore, there is a need to address these four when founding the enabling environment. Particularly, public sector commitment is key as one of the constituent parts of an enabling environment because, at times, governments say one thing but mean a totally different thing. Thus, the PPP enterprise must enjoy support from the first office as happened during the PFI initiative during the Major and Blair governments in the UK. Regarding risk management, it is trite that every endeavor, including PPPs, entails risk; therefore, effective risk management is key. A risk management framework for PPPs must entail some of the following tasks: identifying risks; analyzing risks; prioritizing risks (e.g., mapping out the top five risks); dealing with risks (deploying risk management strategies); and monitoring risks. Regarding the rules of engagement, a legal and regulatory framework is key. Lastly, the success of PPPs is largely contingent upon capable public and private sectors. In the main, they must be equal to the task of delivering PPPs.

Once the enabling environment has been founded, other things can be done. In this regard, the Governmental Project Implementation System (GPIS) and Governmental Project Management (GPM) need to be reformed because they are primary conduits for delivering public projects. Due to poorly functioning GPIS and GPM in a majority of SSA countries, public projects are rarely delivered as per the Project Management Triangle (called also the Triple Constraint, Iron Triangle and Project Triangle) of cost/budget, scope or quality, and time. PPPs demand high project management maturity as instanced by functioning GPIS and GPM; therefore, there is a need to make improvements in these project delivery tools. 
Lastly, public project management reforms are imperative. From anecdotal data, it is adducible that, overall, public project management does not lead to Value for Money (VfM), at a minimum, and BVM (Best Value for Money), at a maximum. Hence, there is a need to improve public project management by, among others, introducing innovations such as Blockchain technology to deliver PPPs. Blockchain technology, based on peer-to-peer (P2P) networking, is a ledger system that allows data to be stored in many servers all over the world. This, therefore, allows anyone connected into the P2P network to see others' inputs in realtime. Among others, it is associated with decentralization, hence, improved operational efficiency. Although to date project management software is used, Blockchain technology is proving superior to the former, hence, suitable for use in PPP projects in SSA countries.

\section{Conclusion}

Resource scarcity, particularly in an era characterized by post-2007 fiscal strictures, ineluctably forces to the fore the question: how should public projects be procured? The answer is often that the choice must result in Value for Money (VfM), at a minimum, or BVM (Best Value for Money), at a maximum. At a broad level, the decision envelope contains (i) traditional public procurement and (ii) PPP. Under the right circumstances, PPP is superior to traditional public procurement for it delivers superior VfM, or BVM. Sub-Saharan Africa (SSA) presents project management maturity challenges as amply instanced by poor Governmental Project Implementation System (GPIS) and Governmental Project Management (GPM), so, public procurement is the least efficient tool. In addition, post-2007 fiscal structures are commonplace in SSA. Post-2007, many monocultural economies in SSA are facing a decline in export prices and volumes. Therefore, there are acute financing challenges. Latterly, the COVID-19 pandemic necessitates economic stimulus packages that demand the participation of the private sector in public infrastructural projects. Thus, three factors, being project management maturity challenges, post-2007 fiscal strictures, and COVID-19 pandemic, provide a compelling case for the adoption of PPPs in SSA. However, a warning must be sounded that PPPs are not silver bullets for they are inherently risky. Therefore, although PPPs provide superior VfM or BVM compared to traditional public procurement, a few fundamentals, chiefly an enabling environment, are key. Once the fundamentals are in place, coupled with improvements in GPIS and GPM and adoption of Blockchain technology, PPPs will potentially lead to project success as per the Project Management Triangle. Should this happen, PPPs will deliver growth and development.

\section{Cross-References}

- Fiscal Stress

- Public Expenditure and

- Public Finance Management Reform

- Public Financial Management

$>$ Revenue Sources

\section{References}

Burger P, Hawkesworth I (2011) How to attain value for money: comparing PPP and traditional infrastructure public procurement. OECD J Budget 1:1-56

Chan APC, Lam PTI, Chan DWM, Cheung E, Ke Y (2009) Drivers for adopting public private partnerships empirical comparison between China and Hong Kong special administrative region. J Constr Eng Manag 135(11):1115-1124

Charles N (2006) Public private partnerships as modes of procuring public infrastructure and service delivery in developing countries: lessons from Uganda. International public procurement conference proceedings, 21-23 September, Rome. http://ippa.org/images/PRO CEEDINGS/IPPC2/Article_26_Charles.pdf. Accessed 4 Apr 2019

Dimitri N (2013) Best value for money in procurement. J Public Procurement 13(2):149-175

Ika LA (2012) Project Management for development in Africa: why projects are failing and what can be done about it. Proj Manag J Spec Issue Manag Proj Afr 43(4):27-41

Public-Private Infrastructure Advisory Facility (PPIAF) (2009) Tool kit for Public-Private Partnerships in roads and highways. https://ppiaf.org/sites/ppiaf.org/files/docu ments/toolkits/highwaystoolkit/6/pdf-version/1-21.pdf. Accessed 10 Feb 2019 
Savas ES (2000) Privatization and public-private partnerships. Chatham House, New York

UK National Audit Office (2020) Assessing value for money https://www.nao.org.uk/successful-commissioning/ge neral-principles/value-for-money/assessing-value-formoney/. Accessed 27 Mar 2020

World Bank (2013) Value-for-money analysis - practices and challenges: how governments choose when to use
PPP to deliver public infrastructure and services. World Bank, Washington, DC

World Bank (2016) Government objectives: benefits and risks of PPPs. https://ppp.worldbank.org/public-privatepartnership/overview/ppp-objectives. Accessed $30 \mathrm{Nov}$ 2019

Zhang X (2005) Paving the way for public-private partnerships in infrastructure development. J Constr Eng Manag 131(1):71-80 